\title{
THE COMPETITIVENESS OF ZIMBABWE'S EXPORTS TO SOUTH AFRICA DURING THE RECOVERY PERIOD 2009 TO 2011
}

\author{
Willie Nakunyada* \\ Reserve Bank of Zimbabwe \\ wnakunyada@rbz.co.zw \\ Laurine Chikoko* \\ Midlands State University \\ chikokol@msu.ac.za
}

Received: September 2012

Accepted: July 2013

\begin{abstract}
This article analyses the competitiveness of Zimbabwe's exports in the South African market under the multiple currency system from 2009 to 2011 . Using real exchange rate analysis and the Revealed Symmetric Comparative Advantage index (RSCA), the article confirms that Zimbabwean products have lost competitiveness in South Africa, with comparative advantage only remaining in a narrow range of primary products. Based on the results, we recommend that deliberate policies be instituted to diversify and enhance the competitiveness of Zimbabwe's exports.
\end{abstract}

Keywords

Export Competitiveness, Comparative Advantage, Effective Exchange Rates, Revealed Symmetric Comparative Advantage, Revealed Comparative Advantage

\#Dr Willie Nakunyada is the Chief $\varepsilon$ conomist in the $\varepsilon$ conomic Research and Policy Enhancement Division at the Reserve Bank of Zimbabwe, Zimbabwe.

+Dr Laurine Chikoko is a lecturer in the Department of Banking and Finance, Midlands State University, Zimbabwe. 


\section{INTRODUCTION}

Zimbabwe adopted a multiple currency system in 2009 following hyperinflationary episodes that characterised the economy from the turn of the century. The shortcomings of this monetary regime in promoting export-led growth present scope for a detailed enquiry. There is general consensus on the other benefits that accompanied the adoption of the multiple currency system, notably macro-economic stability and improved industrial capacity utilisation. This notwithstanding, the competitiveness of the country's exports under the multiple currency system, where price and macro-economic stability confer advantages, remains a topical subject in Zimbabwe.

The adoption of the multiple currency system in Zimbabwe was preceded by a decade-long progressive loss of export competitiveness. This was largely a result of the exponential growth in inflation at a time when the official exchange rate lagged behind developments on the inflation front. In consequence, the real effective exchange rate appreciated progressively, resulting in a loss of export competitiveness during the crisis period that occurred from 2000 to 2008.

In addition, exchange controls taxed exporters and negatively affected their viability as well as the competitiveness of their products in regional and international markets. Against this background, the multiple currency system was envisaged to eliminate exchange rate distortions that had grown to be an export constraint. Under the multiple currency system, the country, however, lost monetary policy autonomy, resulting in the non-existence of interest and exchange rates as potent policy instruments to absorb both domestic and external shocks.

It is within this context that Emanuel (2002) argued that dollarisation confers unfair disadvantages, as other competing nations can resort to exchange rate policy measures to enhance export competitiveness. In the Zimbabwean context, the country continues to absorb huge amounts of imports to bridge attendant supply gaps in the economy, yet the exchange rate is no longer at the Central Bank's disposal to effect the desired outcome as evidenced by the deteriorating trade balance. The country's ability to resort to tariff measures is also constrained by commitments to regional integration initiatives in the context of SADC and COMESA. These initiatives should instead see member states phasing out tariff and non-tariff barriers as the region graduates into a customs union and deeper regional integration.

In view of this negative development, the need to restore export competitiveness following a decade-long decline in export performance cannot be over-emphasised, as government endeavours to promote sustained economic growth and development. This is particularly so as the rejuvenation of the country's key productive sectors, namely agriculture, mining, and manufacturing, is contingent upon improved export competitiveness. Additionally, improved export competitiveness remains key to efforts to build foreign exchange reserve buffers to cushion the country against the vagaries of external shocks that commonly affect countries that have limited policy options, such as Zimbabwe.

Export competitiveness, which is a prerequisite for the attainment of meaningful export growth and diversification, remains a decisive contributor to sustained economic growth and development. Accordingly, increased export performance fosters productivity improvements through numerous channels - notably, the mobilisation of foreign exchange earnings critical to the financing of imported capital equipment. Perhaps most importantly, improved export performance is both indicative of and conducive to the advancement of technology. 
Exports also contribute to poverty reduction through employment generation and will accelerate developing countries' attainment of the Millennium Development Goals (MDGs) targeted for 2015. Studies by UNCTAD, the World Bank and the International Labour Organization (ILO) confirm that workers in export sectors have higher incomes than those engaged in production for the domestic market, particularly in subsistence agriculture and the informal sector (UNCTAD, 2008). Moreover, exports promote technological advancement and efficiency, and labour productivity also rises, thereby boosting incomes.

For small open economies, improved export performance is vital to sustaining growth and vitality (Saboniene, 2009). In turn, export development contributes to improved capital inflows, employment, expansion of industry and widening of the country's production base. Export development also allows domestic industries to achieve economies of scale, which otherwise would not have been possible due to the limited domestic market size. It is against this background that this article seeks to analyse the competitiveness of Zimbabwe's exports within the multiple-currency system with a view to recommending appropriate policy advice.

The rest of the article is organised as follows: section 2 reviews both the theoretical and empirical literature on the measurement and analysis of export competitiveness. Section 3 synthesises the results of the literature reviewed to inform the research methodology adopted for this study. Section 4 analyses the research findings and Section 5 concludes the article by suggesting appropriate policy advice and recommendations.

\section{LITERATURE REVIEW}

Export competitiveness is defined as the ability of a country to produce and sell goods and services in foreign markets at prices and quality that ensure long-term viability and sustainability. Lipsey (1994) shows that export competitiveness can be measured by the export price index, which consists of the following elements: cost of raw materials and intermediate goods, which are primarily imported; labour cost, which includes employees' remuneration and normal profits; rentals, utilities and other fees; and supernormal profit mark-up.

Mbekeani (2007) contends that infrastructure development is a key element of a country's ability to produce and move goods. As such, weak infrastructure is a major impediment to trade, competitiveness and sustainable development in most African countries, particularly landlocked and small island countries.

In this context, Kaminski and Francis (2011) confirmed that in the case of Zimbabwe, policy procedures and infrastructure have resulted in increased costs which adversely affect export competitiveness. As shown in Figure 1 below, Zimbabwe's policy- and infrastructure-induced costs compare unfavourably with those of neighbouring countries such as Zambia, Botswana, Mozambique and South Africa. 


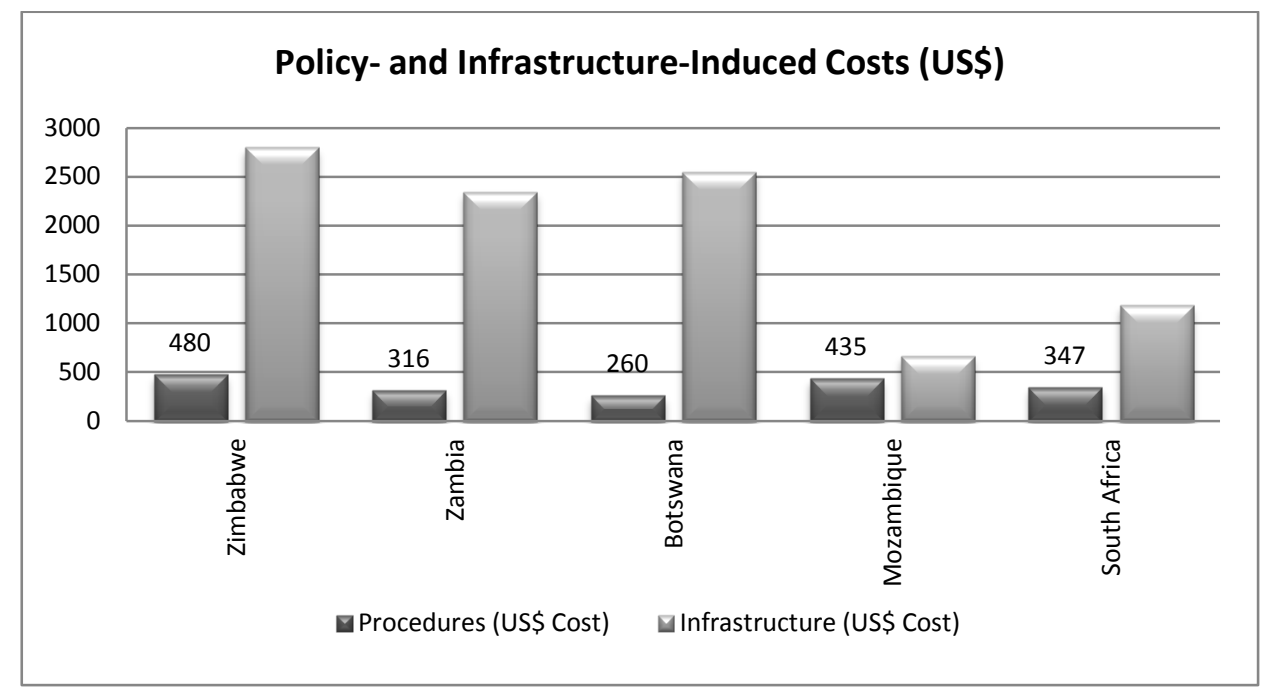

FIGURE la: Policy and Infrastructure Induced Costs

Source: Kaminski and Francis (2011)

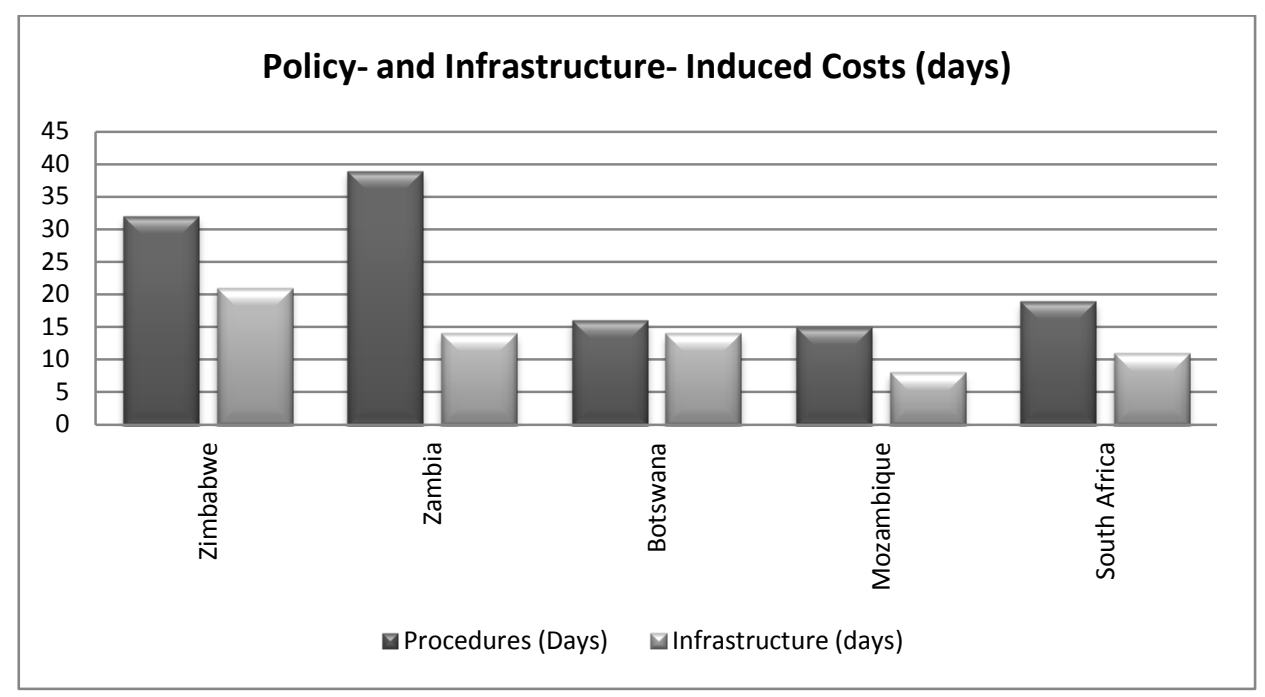

FIGURE 1b: Policy and Infrastructure Induced Costs

Source: Kaminski and Francis (2011)

An overview of the empirical literature reveals that numerous studies used the following methods to measure the competitiveness of a country's exports:

- The Real Effective Exchange Rate;

- The Revealed Comparative Advantage; and

- The Revealed Symmetric Comparative Advantage. 


\subsection{Real Effective Exchange Rate}

Neary (2006) broadly measured competitiveness using the real effective exchange rate. The study emphasised that bilateral competitiveness can be measured by relative consumer prices, relative export unit values, or relative unit labour costs (wages corrected for labour productivity). Following a review of the literature, Cerra, Soikkeli, and Saxena (2003) pointed out that industries may differ in their exposure to competition from foreign countries, so they proposed the following equation:

$$
R E E R=\sum W_{i} \sum \theta_{i}^{j} e^{j} \frac{U L C^{H}}{U L C^{j}}
$$

Where:

$\theta^{j}$ is the share of country $j$ in country $H^{\prime}$ s trade, and $e_{j}$ is the bilateral nominal exchange rate (the home price of a unit of foreign currency).

$W_{i}$ represents industry weights

$U L C^{H}$ is unit labour cost in Home Country

$U L C^{j}$ is unit labour cost in the jth trading partner

Similarly, Esteves and Reis (2005) measured the competitiveness of Portuguese exports using the effective exchange rates. Their study, however, used traditional effective exchange rate indices adjusted for the double-weighted scheme to account for competition from third economies in export markets. Competition in third markets was evaluated in order to account for the different product specialisation of each country. Turner and Golub (1997), however, argued that labour is the most important non-tradable input and as such the unit labour cost is the most important determinant of the international competitiveness of industry. Unit Labour Cost (ULC) is defined as the cost of labour required to produce one unit of output in a particular industry, sector or the total economy.

According to Hacihasanoglu (2007), ULC is alternatively defined as the ratio of labour compensation per unit of labour (measured as wage per employed person or per hour worked). As such, countries with low ULC relative to other countries are regarded as cost competitive. This study used the augmented Unit Labour Cost model expressed as follows:

$$
X=\beta_{0}+\beta_{1} X_{t-1}+\beta_{2} \text { Wage }+\beta_{3} \text { Productivity }+\beta_{4} R E E R+\beta_{5} Y+\beta_{6} \text { Crisis }+e
$$

where $X$ is the volume of exports, $X_{t-1}$ is the lagged value of exports, $R E E R$ is the real effective exchange rate, Crisis is the dummy variable to capture the crisis pre-2001 era, and $Y$ is growth in world export volume, Productivity and Wage are the components of the Unit Labour Cost (ULC). The study, which employed the dynamic panel data method, revealed that labour productivity is the major determinant of export competitiveness in Turkey's manufacturing sector. Additionally, the study confirmed that the rise in nominal wages adversely affected export growth. As such, the promotion of productivity is critical to efforts geared at improving export competitiveness. Other studies, however, used the revealed comparative advantage methods to determine the competitiveness of a country's exports. 


\subsection{Revealed Comparative Advantage (RCA) and Revealed Symmetric Comparative Advantage (RSCA)}

A study by Prasad (2004) on Fiji's export competitiveness used the Revealed Comparative Advantage (RCA) Index and related indices, especially Revealed Symmetric Comparative Advantage (RSCA), to measure Fiji's competitiveness in comparison to a set of reference countries. Results of the RCA and RSCA revealed competitive advantage in several commodities produced by Fiji over the period 1998 to 2002. Tekere (2001) also used the Revealed Comparative Advantage Index over the period 1990 to 1998 to determine Zimbabwe's relative export shares to world trade. The following formula was used in Tekere's study:

$$
R C A_{i}^{j}=\frac{E_{i}^{j} / E_{\text {tot }}^{j}}{E_{i}^{\text {world }} / E_{\text {total }}^{\text {world }}}
$$

where:

$$
\begin{array}{ll}
R C A_{i}^{j} & \text { represents country } \rho \text { 's revealed comparative advantage index for product group } i \\
E_{i}^{j} & \text { represents exports of product } i \text { by exporter } j \\
E_{\text {tot }}^{j} & \text { represents total exports of country } j \\
E_{i}^{\text {world }} & \text { represents world exports of commodity } i \\
E_{\text {total }}^{\text {world }} & \text { represents total world exports. }
\end{array}
$$

The study confirmed that the RCA index generally declined over the period of analysis, reflecting that Zimbabwe lost comparative advantage, notably for agricultural exports. In the context of dollarisation, Quispe-Agnoli (2002) revealed that dollarisation is normally associated with the elimination of exchange rate risks. In the case of Ecuador, the real effective exchange rate appreciated pursuant to dollarisation. This negative development had adverse effects on the competitiveness of Ecuador's exports.

\section{METHODOLOGY}

Reflecting the synthesis of both the theoretical and empirical literature reviewed in the foregoing and attendant data constraints, the study uses the Bilateral Real Exchange Rate analysis over the period under review. In addition, the study also analyses Zimbabwe's comparative advantage using the Revealed Symmetric Comparative Advantage index.

\subsection{Bilateral Real Exchange Rates Equation}

The following formulae for the bilateral real exchange rate (BRER) is used:

$$
\operatorname{BRER}_{f c}=\frac{E_{f c} * P_{G d}}{P_{G f}}
$$

where:

$\boldsymbol{B} \boldsymbol{R} \boldsymbol{E} \boldsymbol{R}_{\boldsymbol{f} \boldsymbol{c}}$ is the Bilateral Real Exchange Rate index, defined as units of foreign currency per unit of the domestic currency. 


$$
\begin{array}{ll}
\boldsymbol{P}_{\boldsymbol{G d}} & \text { represents the CPI for Zimbabwe under the multiple currency system } \\
\boldsymbol{P}_{\boldsymbol{G f}} & \text { represents the CPI for South Africa. } \\
\boldsymbol{E}_{\boldsymbol{f} \boldsymbol{c}} & \text { represents the indirectly quoted US\$/rand exchange rate. }
\end{array}
$$

In this instance, the nominal exchange rate is indirectly quoted for ease of interpretation. As such, a decline in the BRER represents depreciation, while increases represent an appreciation. To the extent that South Africa is Zimbabwe's largest trading partner - accounting for $56 \%$ of exports and $52 \%$ of imports (Ministry of Finance, 2011) - the BRER is computed between Zimbabwe and South Africa. In the absence of a local currency the conventional BRER is modified to include Zimbabwe's CPI under the multiple currency system, which is applied to the US\$/rand exchange rate to determine the cost of Zimbabwe's goods relative to rival products in South Africa.

\subsection{Revealed Comparative Advantage (RCA) Equation}

The study also uses the Revealed Comparative Advantage Index which is computed in relation to South Africa. Accordingly, the formula is modified as follows, to allow for cross-country comparisons:

$$
R C A_{i}^{Z}=\frac{E_{i}^{Z} / E_{\text {tot }}^{Z}}{E_{i}^{S A} / E_{\text {total }}^{S A}}
$$

where:

$$
\begin{array}{ll}
R C A_{i}^{Z} & \text { represents Zimbabwe's revealed comparative advantage index for product group } \\
& i . \\
E_{i}^{Z} & \text { represents Zimbabwe's exports of product } i \\
E_{\text {tot }}^{Z} & \text { represents total exports of Zimbabwe } \\
E_{i}^{S A} & \text { represents South Africa's exports of commodity } i . \\
E_{\text {total }}^{S A} & \text { represents South Africa's total exports. }
\end{array}
$$

The shortcomings of the RCA, however, gave rise to the Revealed Symmetric Comparative Advantage (RSCA) method.

\subsection{Revealed Symmetric Comparative Advantage (RSCA) Equation}

According to Laursen (1998:5), because the RCA turns out to produce an output which cannot be compared for values greater than or less than 1 , the index is made symmetric as follows:

$$
R S C A=\frac{(R C A-1)}{(R C A+1)}
$$

Any result of the Revealed Symmetric Comparative Advantage index (RSCA) that is negative reveals a comparative disadvantage, while any result that is positive reflects areas in which a country has a comparative advantage. 


\subsection{Data sources}

To ascertain the competitiveness of Zimbabwe's exports to South Africa, this study used secondary data on nominal exchange rates and consumer price indices for both Zimbabwe and South Africa to compute the bilateral real exchange rate. Data on these variables is derived from online database found on the South African Reserve Bank website (www.resbank.co.za accessed on 20 January 2012) as well as the Reserve Bank of Zimbabwe data. The CPIs were rebased to a common base (December 2008) as is required by the purchasing power parity theory of exchange rates. Similarly, the exchange rate was rebased into an index sharing the same base period as the CPI indices for Zimbabwe and South Africa. On the other hand, the computation of the Relative Symmetric Comparative Advantage index used trade statistics between Zimbabwe and South Africa as compiled by the South African Revenue Services (SARS) on its website www.sars.co.za.

This study analyses key findings with special focus on the trends of the BRER to ascertain export competitiveness trends in Zimbabwe during the period of analysis. Importantly, results of the RSCA reveal trends in the country's comparative advantage covering 23 selected product categories that Zimbabwe currently exports to the South African market. The study therefore considers only products that Zimbabwe exports to South Africa.

\section{ANALYSIS AND INTEPRETATION OF RESEARCH FINDINGS}

As outlined in the methodology section, the conventional bilateral exchange rate formula was modified in this study to cater for the peculiar multi-currency system prevailing in Zimbabwe over the period of analysis. Accordingly, the study compares CPI for the domestic economy (Zimbabwe) with the CPI for South Africa, its major trading partner, while the nominal exchange rate applied is that between the South African rand and the US\$. This is largely so because the US\$ is the dominant currency used in Zimbabwe under the multiple currency arrangement, and exports are also denominated in US\$.

\subsection{Results of Exchange Rate Indices}

The nominal exchange rate between the South African rand and the US\$ is indirectly quoted (expressed as the number of US\$ per unit of the South African rand) for ease of interpretation. Accordingly, the rise in either the BNER or the BRER represents an appreciation, while a decline represents a depreciation of both exchange rate indices.

In 2009 and 2010, South Africa experienced an influx of portfolio investment flows benefitting from tight liquidity conditions and depressed returns on investment that prevailed in the global capital markets. Increased short-term capital inflows in search of favourable returns in South Africa resulted in the appreciation of the South African rand, a development that militates against the competitiveness of Zimbabwean exports in the South African market. In consequence, the Bilateral Nominal Exchange rate (BNER) appreciated as depicted in FIGURE 2. 


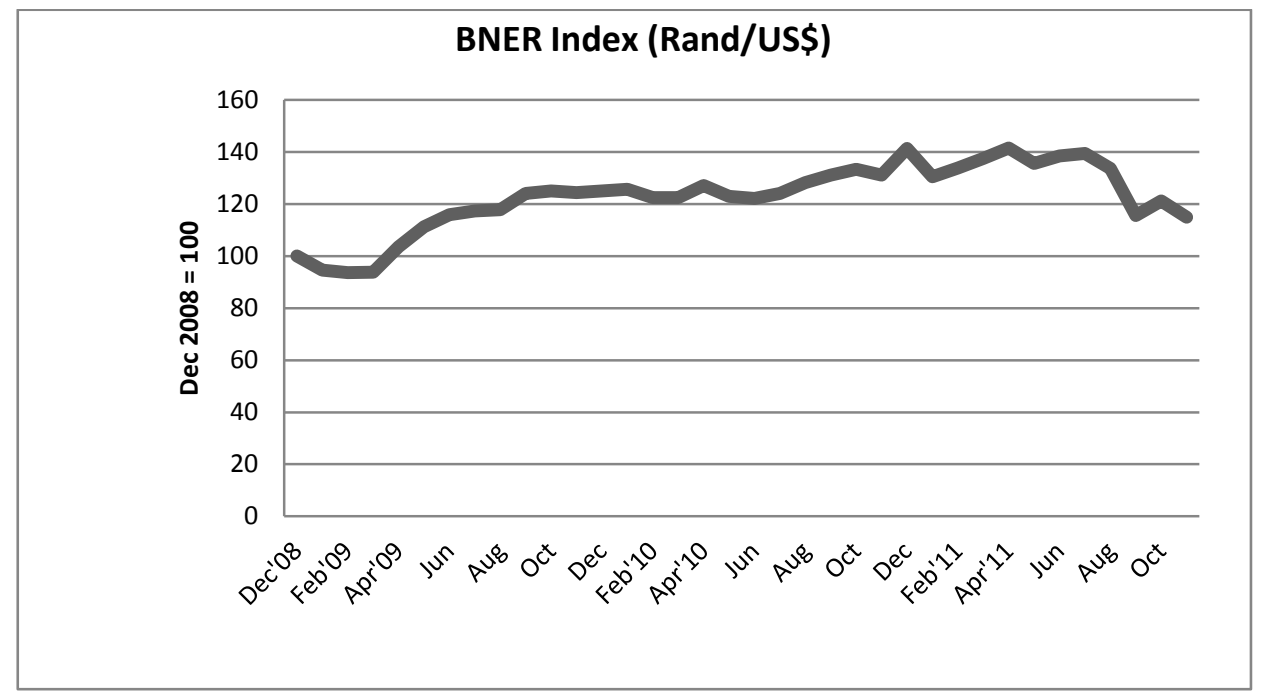

FIGURE 2a: Bilateral Nominal and Real Exchange Rates

Source: Reserve Bank of Zimbabwe (2009)

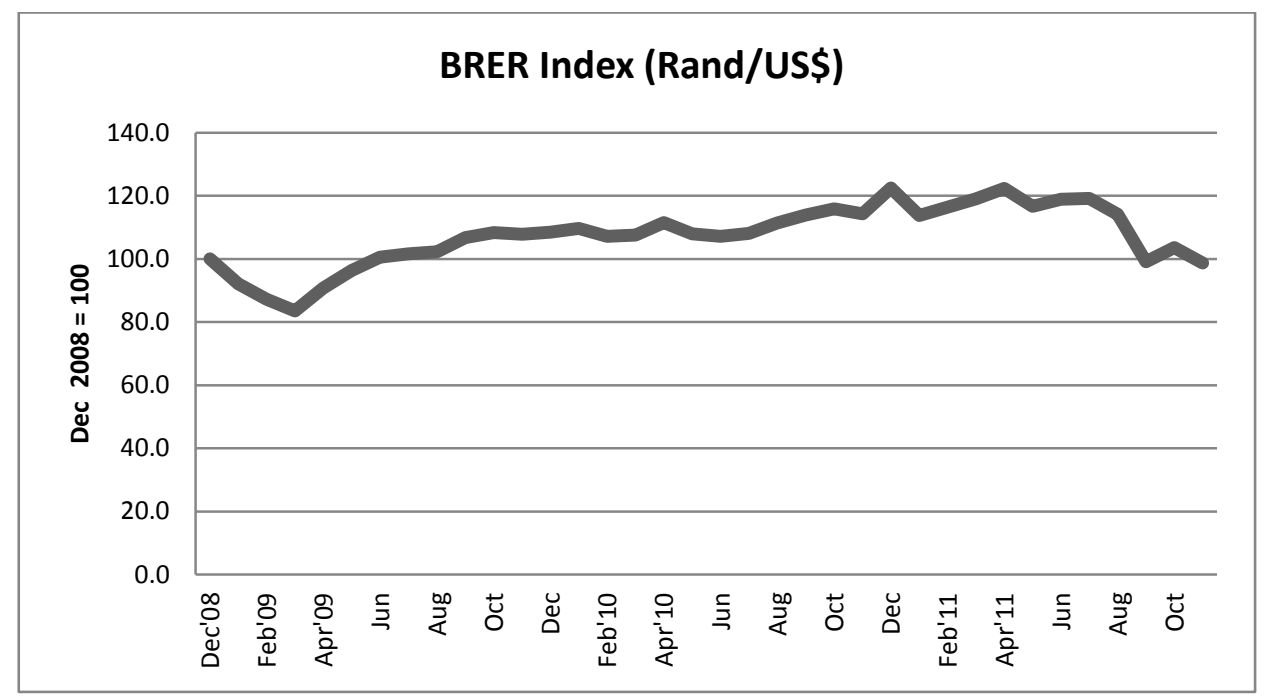

\section{FIGURE 2b: Bilateral Nominal and Real Exchange Rates}

\section{Source: Reserve Bank of Zimbabwe (2009)}

In view of the strong trade and economic ties between Zimbabwe and South Africa, the appreciation of the South African rand generated inflationary pressures, particularly in view of the protracted supply gaps in the Zimbabwean economy. This in turn threatened the competitiveness of Zimbabwe's exports in other markets outside South Africa. As shown in Figure 3 below, notwithstanding the appreciation of the South African rand occasioned by the inflow of portfolio investments, inflation in South Africa remained higher than that of Zimbabwe over the period 2009 to October 2011. 


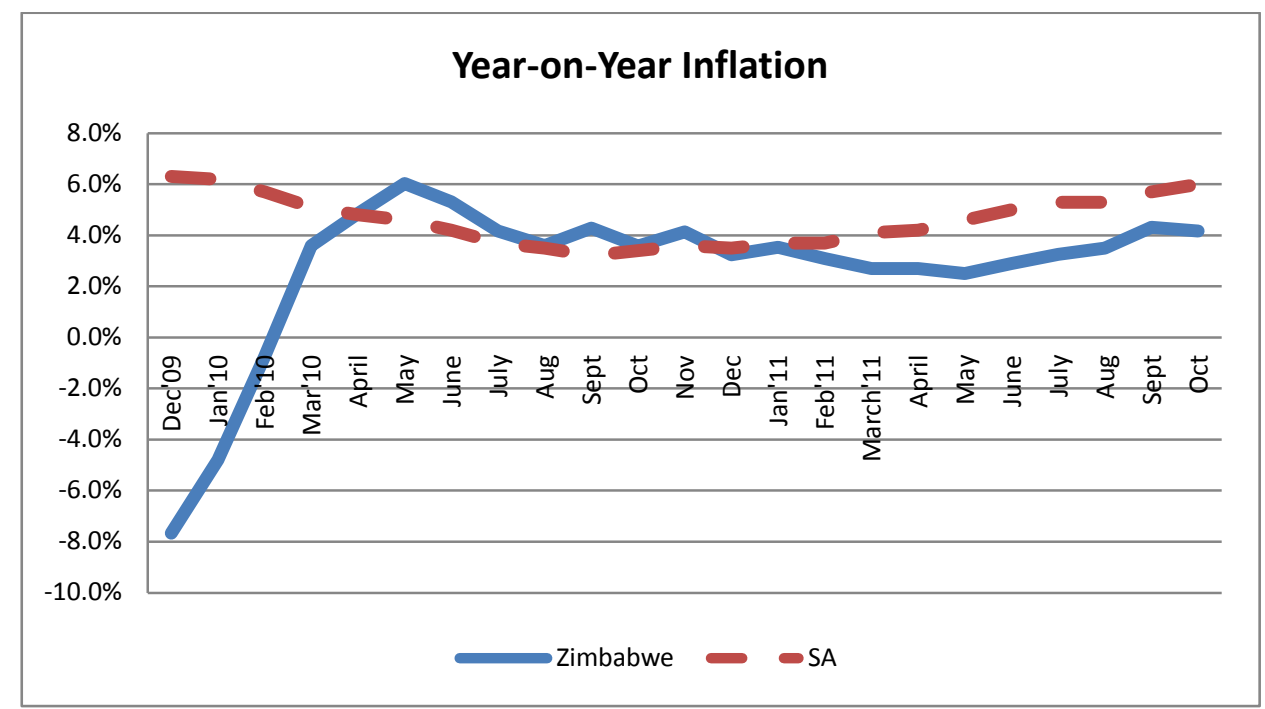

Figure 3: Year-on-Year Inflation in Zimbabwe and South Africa (\%)

Source: Zimstats (2011 and 2012); Statistics South Africa (2011)

These developments on balance culminated in the progressive appreciation of the Bilateral Real Exchange Rate (BRER) between the South African rand and the US\$ adjusted for Zimbabwe's domestic inflation. The BRER index, however, depreciated from 100 (base period) in December 2008 to 83.6 in March 2009, reflecting the improved competitiveness of Zimbabwe's exports. The depreciation in the BRER was largely underpinned by a nominal depreciation in the rand from R9.4/US\$ in December 2008 to record levels of R10/US\$ in March 2009. Subsequently, the BRER appreciated from 83.6 in March 2009 to peak levels of 122.4 in April 2011 on the back of rising domestic inflation in the Zimbabwean economy from year-on-year levels of minus $7.7 \%$ in December 2009 to peak at $6.03 \%$ in May 2010 before declining somewhat to levels below $5 \%$ thereafter.

Zimbabwean exports lost competitiveness during the period of analysis owing to rising domestic inflation arising from increased utility tariffs by Zimbabwe Electricity Supply Authority (ZESA), as well as the introduction of a duty on basic commodities in 2011, the bulk of which are imported from South Africa. Additional inflationary pressures emanated from rising international oil prices in the wake of widespread political instability in North Africa and the Middle East experienced in 2011. Rising global food prices particularly for corn occasioned by the increased demand for corn in bio-fuels production also exerted inflationary pressures on the Zimbabwean economy during the period of analysis.

The depreciation of the South African rand against the US\$ as evidenced by the retreat in the BNER since July 2011, however, resulted in improved competitiveness of Zimbabwe's exports in the South African market. Nonetheless, the adoption of multi-currencies resulted in the loss of monetary policy autonomy. Exchange rate developments, which are key in determining export competitiveness, therefore remained exogenously determined. In this regard, government's policy space was constrained in respect of its ability to effectively deal with adverse domestic and external shocks under the multiple currency regime. 


\subsection{Findings of the Revealed Symmetric Comparative Advantage}

Following the computation of the Revealed Comparative Advantage (RCA) index, adjustments were made to ensure symmetry in the results in order to come up with the Revealed Symmetric Comparative Advantage index results shown in TABLE 1.

\section{TABLE 1: Revealed Symmetric Comparative Advantage (RSCA)}

\begin{tabular}{|c|c|c|c|c|}
\hline Section & HS Description & 2009 & $\begin{array}{l}R S C A \\
2010\end{array}$ & 2011 \\
\hline 1 & Live animals, animal products. & -0.90 & -0.89 & -0.69 \\
\hline 2 & Vegetable products. & 0.25 & 0.26 & -0.14 \\
\hline 3 & $\begin{array}{l}\text { Animal or vegetable fats and oils and their } \\
\text { cleavage products; prepared edible fats; } \\
\text { animal or vegetable waxes. }\end{array}$ & -1.00 & -0.87 & -1.00 \\
\hline 4 & $\begin{array}{l}\text { Prepared foodstuffs, beverages, spirits, and } \\
\text { vinegar; tobacco, \& manufactured tobacco } \\
\text { substitutes. }\end{array}$ & 0.70 & 0.81 & 0.73 \\
\hline 5 & Mineral products. & -0.62 & -0.41 & 0.19 \\
\hline 6 & Products of the chemicals or allied industries. & -0.62 & -0.80 & -0.82 \\
\hline 7 & $\begin{array}{l}\text { Plastics and articles thereof; rubber and } \\
\text { articles thereof. }\end{array}$ & -0.20 & -0.30 & -0.62 \\
\hline 8 & $\begin{array}{l}\text { Raw hides and skins, leather, fur skins and } \\
\text { articles thereof; saddler and harness, travel } \\
\text { articles, handbags and similar containers; } \\
\text { articles of animal gut (other than silkworm- } \\
\text { gut). }\end{array}$ & 0.31 & 0.38 & 0.29 \\
\hline 9 & $\begin{array}{l}\text { Wood and articles of wood, wood charcoal, } \\
\text { cork and articles of cork, manufactures of } \\
\text { straw, of esparto or of other plaiting material, } \\
\text { basket ware and wickerwork. }\end{array}$ & 0.81 & 0.78 & 0.65 \\
\hline 10 & $\begin{array}{l}\text { Pulp of wood or of other fibrous cellulosic } \\
\text { material; waste and scrap of paper or of } \\
\text { paperboard; paper and paperboard and } \\
\text { articles thereof. }\end{array}$ & -0.85 & -0.85 & -0.83 \\
\hline 11 & Textiles and textile articles. & 0.92 & 0.92 & 0.91 \\
\hline 12 & $\begin{array}{l}\text { Footwear, headgear, umbrellas, sun umbrellas, } \\
\text { walking-sticks, seat-sticks, whips, riding- } \\
\text { crops and parts thereof; prepared feathers and } \\
\text { articles made therewith, artificial flowers, } \\
\text { articles of human hair. }\end{array}$ & 0.47 & 0.66 & 0.73 \\
\hline 13 & $\begin{array}{l}\text { Articles of stone, plaster, cement, asbestos, } \\
\text { mica or similar materials, ceramic products, } \\
\text { glass and glassware. }\end{array}$ & -0.59 & -0.51 & -0.06 \\
\hline
\end{tabular}




\begin{tabular}{|c|c|c|c|c|}
\hline Section & HS Description & 2009 & $\begin{array}{l}R S C A \\
2010\end{array}$ & 2011 \\
\hline 14 & $\begin{array}{l}\text { Natural or cultured pearls, precious or semi- } \\
\text { precious stones, precious metals, metals clad } \\
\text { with precious metal and articles thereof; } \\
\text { imitation jewellery, coins. }\end{array}$ & -0.96 & -0.95 & -0.39 \\
\hline 15 & Base metals and articles of base metal. & 0.35 & 0.14 & -0.21 \\
\hline 16 & $\begin{array}{l}\text { Machinery and mechanical appliances, } \\
\text { electrical equipment; parts thereof, sound } \\
\text { recorders and reproducers, television image } \\
\text { and sound recorders and reproducers, and } \\
\text { parts and accessories of such articles. }\end{array}$ & -0.47 & -0.34 & -0.72 \\
\hline 17 & $\begin{array}{l}\text { Vehicles, aircraft, vessels and associated } \\
\text { transport equipment. }\end{array}$ & -0.97 & -0.94 & -0.98 \\
\hline 18 & $\begin{array}{l}\text { Optical, photographic, cinematographic, } \\
\text { measuring, checking, precision, medical or } \\
\text { surgical instruments and apparatus, clocks } \\
\text { and watches, musical instruments; parts and } \\
\text { accessories thereof. }\end{array}$ & -0.93 & -0.69 & -0.96 \\
\hline 20 & Miscellaneous manufactured articles. & 0.32 & 0.52 & -0.26 \\
\hline 21 & Works of art, collectors' pieces and antiques. & 0.65 & 0.58 & 0.31 \\
\hline 22 & Other unclassified goods. & -0.83 & -0.89 & -0.86 \\
\hline 23 & $\begin{array}{l}\text { Special classification provisions: Original } \\
\text { Equipment Components }\end{array}$ & -1.00 & -1.00 & -1.00 \\
\hline
\end{tabular}

Source: Authors' analysis

All positive RSCA reflects areas in which Zimbabwe has a comparative advantage and should specialise in, while negative RSCA represents commodities in which Zimbabwe has a comparative disadvantage. Based on the findings of the computed RSCA as shown in TABLE 1, Zimbabwe consistently has a comparative advantage over South Africa in the following narrow range of products:

- Prepared foodstuffs, beverages, spirits, and vinegar; tobacco and manufactured tobacco substitutes;

- Raw hides and skins, leather, fur skins and articles thereof; saddler and harness, travel articles, handbags and similar containers; articles of animal gut (other than silkworm-gut);

- Wood and articles of wood, wood charcoal, cork and articles of cork, manufactures of straw, of esparto or of other plaiting material, basket ware and wickerwork;

- Textiles and textile articles;

- Footwear, headgear, umbrellas, sun umbrellas, walking-sticks, seat-sticks, whips, ridingcrops and parts thereof; prepared feathers and articles made therewith, artificial flowers, articles of human hair; and

- Works of art, collectors' pieces and antiques. 
The research findings also reveal that Zimbabwe lost comparative advantage to South Africa in vegetable products during the period of analysis but gained comparative advantage in mineral products. Despite recording comparative disadvantages in the rest of the product lines, extreme disadvantages were registered in the following product categories, however:

- Animal or vegetable fats and oils and their cleavage products; prepared edible fats; animal or vegetable waxes; and

- Special classification provisions: Original Equipment Components.

\section{CONCLUSION AND POLICY RECOMMENDATIONS}

\subsection{Conclusion}

Consistent with the results of this study, as obtained using both the real exchange rate analysis as well as the Revealed Asymmetric Comparative Advantage index, Zimbabwe gained export competitiveness in only a narrow range of commodities. Comparative disadvantages, which are indicative of a deterioration in export competitiveness, and in some instances to a great extent, were experienced in relation to some export commodities destined for the South African markets. Accordingly, although the country lost comparative advantage in selected products, it also gained in competitiveness in the South African markets during the recovery period from 2009 to 2011.

Moreover, the appreciation of the South African rand, which is associated with imported inflation from South Africa, has also negatively affected the competitiveness of Zimbabwe's exports to South Africa, which is Zimbabwe's major trading partner. Against this background, the need for appropriate policies as embodied in the recommendations below cannot be overemphasised.

\subsection{Policy recommendations}

Export growth and diversification is a decisive contributor to economic development in developing and developed countries alike. This is particularly so as economic growth is primarily contingent upon increased productivity and efficiency. In turn, improved export competitiveness fosters productivity improvements through a number of channels, including the generation of foreign exchange earnings that finance imports of capital equipment. The advancement of technology in developing countries will provide impetus to the attainment of stringent quality norms required in the developed world. In addition, the latest technology will also assist in the achievement of delivery schedules while containing costs to levels that promote export competitiveness.

Zimbabwe needs to improve its export performance in order to shed its donor dependency and to build adequate foreign exchange buffers in the context of the multiple currency system. In the absence of balance of payments support coupled with limited offshore credit lines, the country's export performance remains the sustainable way to finance its import requirements in order to steer the productive sectors of the economy firmly on a sustainable recovery and growth path.

If Zimbabwe remains a high-cost producer, as is currently the case, both its export products and those produced for the domestic market will be out-competed by low-cost producers. In this regard, the country needs to align its domestic resource costs (raw materials, utilities, 
finance/interest costs, communication and transport) to internationally competitive levels in order to enhance the competitiveness of the country's exports.

There is need to restore agricultural output to pre-crisis levels in order to take advantage of established niche markets for both traditional and non-traditional agricultural products such as tobacco, raw sugar, beef, coffee, tea, horticultural produce and cotton. The scaling up of production of these agricultural products will have downstream benefits for the agro-processing industry and the manufacturing sector at large. This will result not only in improved agricultural exports but in the recovery of manufactured sector output and exports.

In the short to medium term Zimbabwe's growth prospects can be enhanced by improving export competitiveness, particularly in areas where the country has comparative advantages. Increased volatility in international commodity prices and their adverse effects on extractive and primary sectors present a compelling argument for diversification. Diversification broadens the scope for employment creation and poverty reduction, and also increases a country's economic resilience to external shocks, thereby making incomes more stable and predictable. Diversification also has potential to promote technological advancement and efficiency, thereby boosting labour productivity and incomes.

Most importantly, successful export diversification is both indicative of and conducive to technological upgrading and knowledge acquisition. Reliance on a narrow range of primary commodities has deprived the country of significant export earnings. It is against this background that the country should diversify its export basket in order to shed its susceptibility to commodity price shocks that can potentially affect key export sectors of the economy with downstream effects on employment and general living standards.

Zimbabwe relies heavily on the South African market for both its imports and exports. This development has exposed the country to negative effects associated with the strengthening of the South African rand through rising domestic inflation. In turn, this has negatively affected the competitiveness of the country's exports in South Africa and in world markets at large. Although this development augurs well for deepening regional integration, there is need for the country to explore new markets in the region and beyond in order to reduce its vulnerability to adverse economic developments in a single market such as South Africa.

Nevertheless, this study can be broadened to cover other major trading partners for Zimbabwe, notably Botswana, Zambia, China, United States of America, UK, Netherlands, Switzerland, Italy and Spain, among others. In this case the real effective exchange rate index or the multilateral real exchange rate index will be computed using the geometric mean method to ascertain on average the competitiveness of Zimbabwe's exports against major trading partner countries. The study can also be extended to ascertain the country's export competitiveness by comparing unit labour costs or domestic resource costs at large to those obtaining in major trading partners mentioned in the foregoing. Other trade intensity indices can also be used to shed more light on the competitiveness of Zimbabwe's exports.

\section{LIST OF REFERENCES}

Cerra, V., Soikkeli, J. \& Saxena, S.C. (2003). How Competitive Is Irish Manufacturing? Economic and Social Review. The British Library Board, 34(2), pp.173-193. 
Emanuel, C.J. (2002). Dollarisation in Ecuador: a Definite Step Towards a Real Economy. Minister of Economy and Finance of Ecuador. Comunidad Andina.

Esteves, P.S. \& Reis, C. (2005). Measuring Export Competitiveness: A View on the Portuguese Effective Exchange Rate Weights. Banco de Portugal. Economic Bulletin.

Hacihasanoglu, Y.S. (2007). Essays on Determinants of export Competitiveness and Unit Labour Costs. Bogazici University.

Laursen, K. (1998). Revealed Comparative Advantage and Alternatives as measures of International Specialization. Department of Industrial Economics and Strategy. DRUID Copenhagen Business School. Denmark. (Working paper No. 98-30)

Lipsey, R.E. (1994). Price Competitiveness Measures for Exports: Taiwan and its Rivals. Paper Presented at the Pacific Rim Conference. Western Economic Association. Hong Kong.

Kaminski, B. \& Francis, N. (2011). Zimbabwe's Foreign Trade Performance During the Decade of Economic Turmoil: Will Exports Recover. World Bank.

Mbekeani, K.K. (2007). The Role of Infrastructure in Determining Export Competitiveness: Framework Paper. African Economic Research Consortium. Nairobi.

Ministry Of Finance. (2011). National Budget Statement, November

Neary, J.P. (2006). Measuring Competitiveness. IMF Working Paper WP/06/209. Washington D.C. (Working paper no. WP/06/209).

Prasad, R.N. (2004). Fiji's Export Competitiveness: A Comparison with Selected Small Island Developing States. Economics Department. Reserve Bank of Fiji. Suva.

Quispe-Agnoli, M. (2002). Costs and benefits of Dollarisation. Latin America Research Group. Federal Reserve Bank of Atlanta.

Reserve Bank of Zimbabwe. (2009). January and July Monetary Policy Statements.

Saboniene, A. (2009). Lithuanian Export Competitiveness: Comparison with Baltic States. Kaunas University of Technology.

Statistics South Africa. (2011). Consumer Price Index November 2011 Statistical Release.

Tekere, M. (2001). Trade Liberalization Under Structural Economic Adjustment - Impact on Social Welfare in Zimbabwe. Poverty Reduction Forum. SAPRI.

Turner, A.G. \& Golub, S. (1997). Towards a System of Unit Labour Cost-based Competitiveness Indicators for Advanced, Developing and Transition Countries: in Staff Studies of the World Economic Outlook. IMF, 47-60. Washington D.C.

UNCTAD. (2008). Export Competitiveness and Development in LDCs: Policies, Issues and Priorities for Least Developed Countries for Action During and Beyond UNCTAD XII. United Nations. New York and Geneva.

Zimbabwe Statistical Agency (Zimstat). (2011 and 2012). Quarterly Digest of Statistics. 
Nakunyada \& Chikoko 